\title{
A Sustainable Approach to Collect Post-Consumer Textile Waste in Developing Countries
}

\author{
Evrim BUYUKASLAN ${ }^{1}$, Simona JEVŠNIK ${ }^{2}$, Fatma KALAOGLU ${ }^{2}$ \\ ${ }^{1}$ Istanbul Bilgi Universitesi, Fashion Design, Istanbul, Turkey \\ ${ }^{2}$ Istanbul Technical University, Textile Technology and Design Faculty, İstanbul, Turkey
}

\begin{abstract}
Every year million tons of textile waste is being sent to landfills. It is estimated that in Turkey approximately half of the disposed textile waste is consisted of post-consumer textile waste. Although the amount of post-consumer textile waste is as high as pre-consumer textile waste, recovering opportunities for post-consumer textile waste is substantially disregarded. The purpose of this study is to make the preliminary work to investigate potential of post-consumer textile waste and recycling/reusing possibilities in Turkey by monitoring UK and US examples. This study may contribute to developing countries as many of them are lacking of an attempt to collect, recycle or reuse post-consumer textile waste.
\end{abstract}

Keywords: Post-consumer textile waste, sustainability, textile recycling, textile waste disposal behavior

\section{INTRODUCTION}

To apply sustainable practices in fashion context is quite challenging. "Fast fashion" brands such as Zara, H\&M, Primemark and many others shorten the fashion cycle and attune the costumer for consume more. Now costumers are encouraged to buy more garments and dispose only after wearing couple of times [1].

Every year million tons of textile waste is being sent to landfills. Only in Turkey, 287 thousand tons of textile waste was brought to controlled landfills and it is 2.62 percent of municipal solid waste (MSW) [2]. The numbers get massive for developed countries. For instance; it is estimated that 14.3 million tons of textiles were generated in US in 2012 which is 5.7 percent of total MSW [3].

According to Environmental Protection Agency [3] Americans throw away almost $31 \mathrm{~kg}$ of clothing and textiles per person per year. The results are similar in UK. An average UK citizen throws away $30 \mathrm{~kg}$ of clothing and textile waste every year [4]. Developed countries are richer in literature in terms of reports for post-consumer clothing and textile wastes. Unfortunately there is lack of statistics in Turkey to analyze the amount of clothing and textile waste produced by consumers. The only research to analyze household waste in Turkey in national scale dates back to 1993. According to this study 0.6 percent of household waste is textiles [5].
Even though statistics are missing there are several researches that we can consult to estimate post-consumer clothing and textile waste. Altun's study is one of its kind for investigating the disposal of pre-consumer and postconsumer textile waste in Turkey. According to Altun's study, it is estimated that approximately 425 thousand tons of household textiles waste and 458.5 thousand tons of industrial textile waste was generated in 2009 in Turkey [6]. Another study [7] only considers a highly industrial town, Corlu, with many textile factories operating. According to this study an average of 1.41 percent of total municipality waste is household textiles.

The purpose of this study is to make the preliminary work to investigate post-consumer textile waste potential and recycling possibilities in Turkey by monitoring UK and US examples.

\subsection{Recycling Of Textile Waste}

The amount of textile waste produced globally is huge as mentioned recently. Even though textiles are $100 \%$ recyclable [8] the textile recycling ratios are as low as 15 $\%$ even for developed countries such as US [9]. Most of the textile waste unfortunately goes to landfills. One of the biggest textile recycling company owner in US point out that almost 80 percent of textile waste that go to landfills are synthetic while the rest are natural fiber sources [10].

Corresponding Author: Evrim BUYUKASLAN, Tel: +90 (212) 28561 83, E-mail: evrim.buyukaslan@bilgi.edu.tr Submitted: 15 October 2014, Revised: 04 March 2015, Accepted: 01 July 2015 
Theoretically natural fibers decompose over time while synthetics don't. However buried natural fibers also hardly decompose practically. Even though decomposing occurs, toxic leachate or biogases are generated side products due to decomposing. According to Hawley, the recycling materials can be classified as pre-consumer and post-consumer wastes. Textile, fiber and cotton industries produce byproducts during manufacturing process and some of these by-products, in other words pre-consumer wastes, are recycled to be used for automotive, aeronautics, furniture, home building, paper, and apparel industries. Post-consumer products are defined as any garment or household product that owner no longer need and decides to discard [10].

There are several ways to recycle post-consumer textile wastes and almost all of the textile wastes are recyclable. Selling textile items to second hand stores or sending to charities, donating to developing countries, processing back into fibers, re-designing are only some of these textile recycling possibilities [10]. More effort is concentrated on collecting pre-consumer textile wastes and recycling them. There might be several reasons for this. Collecting and recycling pre-consumer textile waste is easier. First of all textile manufacturers can easily assort their textile waste as the waste constituting materials are less varied and more predictable. For instance, a denim manufacturer company's textile waste is expected to be denim fabric. On the other hand a household textile waste may contain clothes, blankets, carpets etc. and the material content can vary such as cotton, silk, linen, polyester, polyamide and many others. Moreover many textile manufacturers are aware of the profitability of the textile wastes. 62 percent of textile manufacturers in Turkey sell their textile wastes to recyclers and provide considerable income [6].

Unlike pre-consumer textile waste, most of the postconsumer textile waste is collected by municipalities together with other household waste and usually buried in municipal landfills. If a systematic collection of household textile waste can be arranged by municipalities, it is estimated that 425 thousand tons/ year of textile waste can be recycled in Turkey [6].

There are several reasons for disposal of a garment. The garment might be out of style and the consumer is no longer interested in keeping it. Poor fit, low quality, worn out, boredom with the garment are some other reasons for disposing garments [11-12]. Moreover the fast fashion industry influence consumer's buying behaviors and consumers are pushed to dispose garments more often.
Over and above fast fashion items are named as "disposable garments" due to very low prices and availability. The trends are now changing quicker more than ever and fast fashion retailers adapt and offer these trends to the consumers with affordable prices. Thus consumers are motivated to displace the garments in their wardrobe with the trendy items in a routine manner [13].

Even though the consumption and disposal of garments are increasing, the societies and individuals are more conscious for recycling their used garments.

As mentioned earlier there are alternative ways to recycle post-consumer textile waste. Unfortunately there is no systematic collection of post-consumer textile wastes in Turkey and no research to report the destiny of used cloths. According to literature a consumer can reveal several behaviors when contemplating disposition; keep it, get rid of it, dispose it only temporary [14]. Turkish people have witnessed poverty during the history so many people keep and store their used cloths for years and wait their children, nephews, nieces to grow to wear them. If not keeping, family members and friends are some common alternatives to give less worn and in good condition cloths. In urban areas historical perspective of recycling of cloths are still prevalent. People reuse their worn cloths to make rugs, mattresses and furniture. Unlikely developed countries, second hand stores are not common. However lately people's perceptions started to change in line with rising vintage trend worldwide thus new vintage shops are opening. Donation is another widespread disposal behavior practiced in Turkey. Collectivist culture of Turkey encourages people to give their unused clothes to the people in need. Especially during national or international disasters, people are more willing to help others thus several governmental and nongovernmental organizations coordinate collection of used clothes and reach to the disaster area. Some municipalities collect used clothing to grant to the people in need as well. However still there is no systematic municipal collection of the used clothes.

Increasing global waste problems might be minimized with the cooperation of academia, business and government as well as consumers [15].

The initiatives should be taken by the governments firstly. US and UK achieved to initiate several organizations to collect post-consumer textile waste to some extent. These organizations encourage consumers to dispose their used cloths in a most environmental way and provide them 
opportunities for re-use or recycling their cloths. Textile Recycling Association (TSA), Secondary Materials and Recycled Textiles (SMART), Waste \& Resourcing Action Programming (WRAP), Council for Textile Recycling (CTR) are some governmental organizations which put an effort to reduce textile waste in UK and US. These organizations offer some road maps to consumers, designers, industry and governments to create more sustainable clothing cycles.

\subsection{Practices to Collect Post-Consumer Textile Waste}

Individuals recycling behaviors should be thought in a context according to General System Theory (GST). According to this theory; local solid waste policies, availability of local charity shops and local attitudes towards recycling influence disposal habits of post-consumer textile wastes [16]. The most important determinant of recycling behavior is convenience [17]. Easy access of collection sites and availability of waste collection bins influence recycling activities [12]. Most of the people in US donate their used garments to professional organizations such as Goodwill and Salvation Army and to other nonprofit organizations [18]. Morgan and Birtwistle's study confirms that UK citizens have similar textiles and clothing disposal behavior to US citizens (Morgan \& Birtwistle, 2009). According to this study the majority of the clothing (36\%) was given to charity shops and $7.4 \%$ was put in textile recycling bins. Oxfam, Salvation Army and Cancer Research are some charity shops which UK participants often donate their unwanted textiles.

Salvation Army is the second biggest charity in US according to Forbes List in 2013 [19]. Salvation Army is a Christian denominational church and international charitable organization. Donations are encouraged to fund "Adult Rehabilitation Centers" where men and women with disability are guided to cope with their problems and provide themselves are rehabilitated. Donations are sold through 1266 thrift shops spread all along US, Canada and Australia. According to Salvation Army's statistics [20] they distributed more than 20 million items of cloths, furniture and gifts. Easy donation ways are offered for citizens. An online reservation is offered for donators to book a suitable time period for their donations to be picked up by organization members. They also provide donation bins near to sites where people densely reside.

Goodwill is another organization that helps people to find suitable jobs and commence training programs for youth, seniors, veterans and people with disabilities to get hired for industries such as IT, banking and health care. Goodwill helped more than 9.8 million people train for careers in different industries. Donations are done via several ways, there are donation sites spread around the country, the donator drop off the clothes to these sites. Goodwill also offers some pick up services. The donated items are sold through 2700 stores or online [21].

Finally Oxfam is an international confederation of 17 organizations working together in more than 90 countries. Oxfam was initially founded in 1995 in Britain and currently The Oxfam International Secretariat is based in Oxford. Oxfam works to find practical, innovative ways to help to fight against poverty and thrive [22]. Oxfam receives clothing donations and sells them in Oxfam shops in all around the world. Donations are made in a manner similar to Goodwill and Salvation Army. There are "Oxfam Clothing Banks" where donators can drop off used clothes or they drop them to Oxfam Stores to be reused or recycled. Only in UK there are more than 700 Oxfam stores where the donations are sold and the revenue is used for fighting against poverty. According to an interview with Cathy Barnes, Oxfam is a quite innovative charity organization with its virtual stores and their actual store locations. Unlikely many thrift stores located in rundown streets, Oxfam stores are located in high streets where many other famous retailers resides [23].

Additionally Oxfam is innovative to locate several donation banks in some music festivals such as Glastonbury to collect unused clothing wastes. As mentioned recently organizations should collaborate with business. Oxfam initiated a new idea in collaboration with Mark\&Spencer in 2012 and developed a new campaign named "Shwopping". According to this campaign, people are asked to bring their used clothing to M\&S or Oxfam stores to receive a $5 £$ voucher for shopping in M\&S. According to the Oxfam's statement, in the very first year of the campaign 6.9 millions of garments were donated.

\section{RESULTS AND DISCUSSION}

Post-consumer textile waste disposal is as important as pre-consumer textile waste. There is more effort to recycle pre-consumer textile waste as it is easier to sort and recycle when compared to post-consumer textile waste. However post-consumer textile waste is almost $100 \%$ recyclable. Unwanted textile and clothes can be donated to charities, given to friends and family members or repurposed in order to use as rags or sheeting. Convenience is the most 
important condition for people to donate their unwanted clothes. Academia, business and governments should work together to increase the donation of post-consumer textile waste and to reduce the amount of waste going to landfills. Initially people behavior for deposing their textile waste should be well defined. The reasons for deposing the garments should be investigated to understand the state of the garments being disposed as this information is especially important for donations. Vintage trends are rising in Turkey in line with the world. Thus valued unwanted goods can be sold through second-hand stores. But it is also reported that there is a missing number of second-hand stores in Turkey, with rising vintage trend the number of secondhand stores should increase. Secondly the post-consumer textile disposing amount should be analyzed. There is statistics missing to find out the post-consumer textile waste per person per year. Finally Turkey is missing to put effort to collect post-consumer textile waste, no governmental neither organizational systematic collection is available. Even though some municipalities offer post-consumer textile waste collection, still a convenient donation site is not offered for Turkish citizens. In this study, it is offered that post-consumer textile waste collection manners might be originated from developed countries such as UK and US as there are several non-profit organizations which collects clothing and textile donations and using revenues for the sake of people in need. According to researches Salvation Army, Goodwill and Oxfam are the biggest non-profit organizations to collect post-consumer textile waste. These organizations' approaches for collecting postconsumer textile waste are appreciated by donators. These organizations provide recycling bins for post-consumer clothing wastes and they have many thrift stores located around where donators can drop off their used clothing. Finally Oxfam has cooperated with business to encourage clothing donation. The "Shwopping" is an innovation to increase clothing donation. Companies offer vouchers to their costumers upon their donation to charities. Oxfam and Marks \& Spencer initiated idea will probably be followed by many other retailers.

Salvation Army, Goodwill and Oxfam examples and their innovative ideas such as clothing waste collection bins, stores to sell donated items, collaboration with business to encourage donations, and locating some bins to collect textile waste in events such as music festivals are some examples to initiate a more effective post-consumer textile waste collection in Turkey.

\section{CONCLUSSION}

This study will shed a light for developing countries to initiate a systematic collection for post-consumer textile waste. However, initially consumer's disposal behaviors for individual countries and cultures should be well defined. Secondly some statistical data are required to understand the quantity of the post-consumer textile waste. Finally, consumers should be provided convenient disposal alternatives. Government, business, organizations and consumers should collaborate to achieve a sustainable system for textile waste disposal. UK and US are two countries which achieved this collaboration to some extend thus further studies for developing countries may be originated from UK and US models.

\section{REFERENCES}

[1] Lee, M., 1997. Fast Fashion. The Ecologist, 37(2), p. 60.

[2] Turkish Statistical Institute, 2008. Amount of Disposed/ Recovered waste brought to controlled landfill sites by type of waste and disposal/recovery methods. [Online] Available at: http://www.turkstat.gov.tr/PreTablo. do?alt_id=1029 [accessed on 03 May 2014].

[3] US Environmental Protection Agency, 2012. Wastes Resource Conservation - Common Wastes \& Materials. [Online] Available at: http://www.epa.gov/epawaste/ conserve/materials/textile.htm [accessed on 18 April 2014].

[4] Allwood, J. M., DeRodriguez, M. C., Bocken, N. M. \& Bocken, N. M., 2006. Well dressed? The present and future sustainability of clothing and textiles in the United Kingdom. [Online] Available at: http:// www.ifm.eng.cam.ac.uk/resources/sustainability/welldressed/ [accessed on 14 May 2014].

[5] State Institute of Statistics of Turkey (SIS), 1993. Environmental Statistics, Household Solid Waste Composition Survey, Ankara

[6] Altun, S., 2012. Prediction of Textile Waste Profiles and Recycling Opportunities in Turkey. Fibres\&Textiles in Eastern Europe, 94(5), pp. 16-20.

[7] Tinmaz, E. \& Demir, İ., 2006. Research on Solid Waste Management System: To improve existing situation in Corlu Town of Turkey. Waste Management, 26(3), pp. 307-314. 
[8] Stall-Meadows, S. \& Peek, G., 2012. Recycled Household Textiles and Clothing. [Online] Available at: http://pods.dasnr.okstate.edu/docushare/dsweb/ View/Collection-627 [accessed on 14 April 2014].

[9] EPA, 2010. Municipal Solid Waste Generation, Recycling, and Disposal in the United States: Facts and Figures for 2010. [Online] Available at: http://www. epa.gov/osw/nonhaz/municipal/pubs/msw_2010 factsheet.pdf [accessed on 12 March 2014].

[10] Hawley, J., 2011. Textile Recycling Options. In: A. Gwilt \& T. Rissanen, Shaping Sustainable Fashion: Changing the way we make and use clothes. London: Eartscan, pp. 143-155.

[11] Shim, S., 1995. Environmentalism and Consumers' Clothing Disposal Patterns: An Exploratory Study. Clothing and Textile Research Journal , 13(1), pp. 3848.

[12] Koch, K. \& Domina, T., 1999. Consumer Textile Recycling as a Means of Solid Waste Reduction. Family and Consumer Science Research Journal , 28(1), pp. 3-17.

[13] Morgan, L. R. \& Birtwistle, G., 2009. An investigation of young fashion consumers' disposal habits. International Journal of Consumer Studies, Vol. 33, pp. 190-198. Oxfam, 2014. Oxfam: About Us. [Online]

[14] Jacoby, J., Berning, C. K. \& Dietvorst, T. F., 1977. What about disposition? Journal of Marketing, 41(2), pp. 22-28.

[15] Wells, W. D., 1993. Discovery-oriented consumer research. Journal of Consumer Research, 19(4), pp. 489-504

[16] Hawley, J. M., 2009. Understanding and improving textile recycling: a system perspective. In: R. S. Blackburn, Sustainable Textiles: Life cycle and environmental impact. s.l.: Woodhead Publishing Limited, pp. 180-199.

[17] Berger, I. E., 1997. The demographics of Recycling and the structure of environmental behavior. Environment and Behavior, Vol. 29, pp. 515-531.

[18] Lee, J. Y., Halter, H., Johnson, K. P. \& Ju, H., 2013. Investigating fashion disposal with young consumers. Young Consumers, 14(1), pp. 67-78.

[19] Forbes, 2013. The Largest U.S. Charities for 2013. [Online] Available at: http://www.forbes.com/topcharities/list [accessed on 8 May 2014].

[20] Salvation Army, 2014. Service Statistics. [Online] Available at: http://www.salvationarmyusa.org/ [accessed on 8 May 2014].

[21] Goodwill, 2014. Goodwill. [Online] Available at: http://www.goodwill.org/donate-and-shop/donatestuff/ [accessed on 7 May 2014].

[22] Available at: http://www.oxfam.org/en/about [accessed on 10 May 2014].

[23] Barnes, C., 2012. The Guardian. [Online] Available at: http://www.theguardian.com/society/shortcuts/2012/ jul/24/oxfam-bucks-high-street-trends [accessed on 18 April 2014]. 